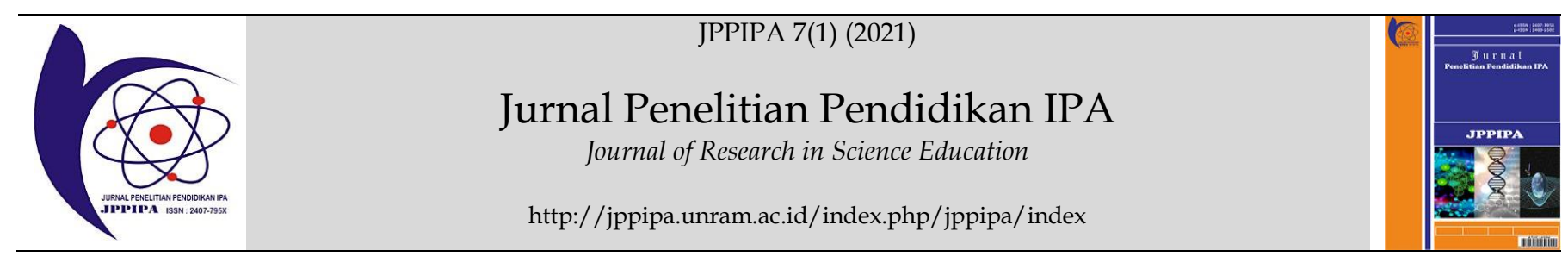

\title{
Ethnoscience-Based Science Learning Model to Develop Critical Thinking Ability and Local Cultural Concern for Junior High School Students in Lombok
}

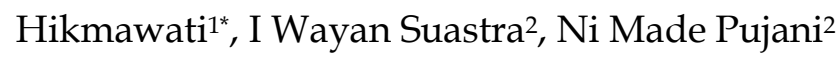 \\ ${ }^{1}$ Program Studi Pendidika Fisika, Universitas Mataram, West Nusa Tenggara, Indonesia \\ ${ }^{2}$ Universitas Pendidikan Ganesha, Bali, Indonesia.
}

\section{DOI: $\underline{10.29303 / \text { ippipa.v7i1.530 }}$}

\section{Article Info}

Received : November $16^{\text {th }}, 2020$

Revised : December 25th, 2020

Accepted: December 31th, 2020

\begin{abstract}
This study aims to analyze the needs of students in learning science in junior high schools which will be used as a basis in designing ethnoscience-based learning models for the development of critical thinking skills and concern for students' local culture. Teachers who were used as samples of this study were 30 junior high school science teachers in Lombok. Data were collected through field observations, literature review, questionnaires, and interviews. Data were analyzed descriptively. Based on the results of data analysis, it can be concluded that: 1) There are 5 basic competencies that can be developed in ethnoscience-based learning. 2) Methods suitable for ethnoscience-based learning are investigation/experimentation, field observation, and discussion. 3) Suitable learning resources to support science learning are the natural and socio-cultural environment, textbooks, audio visuals, and the internet. 4) The assessment system suitable for ethnoscience-based science learning to develop students' critical thinking skills and local cultural awareness is non-test assessment (performance, attitudes, portfolios, products) and assessment by tests. 5) Critical thinking skills that can be developed are: Providing simple explanations, building basic skills, concluding, making further explanations, strategies and tactics. 6) Local cultural concerns that can be developed are liking local culture, introducing local culture to others, preserving local culture. 7) Conceptual model of ethnoscience-based science learning which is suitable for developing critical thinking skills and local cultural awareness includes the following steps: Engage, Explore, Explain, Elaborate, Exhibit, and Evaluate.
\end{abstract}

Keywords: Ethnoscience; critical thinking; culture.

Citation: Hikmawati, H., Suastra, I., \& Pujani, N. (2020). Ethnoscience-Based Science Learning Model to Develop Critical Thinking Ability and Local Cultural Concern for Junior High School Students in Lombok. Jurnal Penelitian Pendidikan IPA, 7(1), 60-66. doi:https:// doi.org/10.29303/jppipa.v7i1.530

\section{Introduction}

Low science learning outcomes and concern for student culture need attention from all parties. Based on the newly released PISA report, Tuesday 3 December 2019, Indonesian students' science scores rank 70 out of 78 countries. This score decreased from the 2015 PISA test, which at that time the science score of Indonesian students was ranked 64 (OECD, 2019).
Meanwhile, the development of technology and information has had a negative impact, namely that students currently lack a caring attitude and love culture. One effort that can be done is to introduce cultural values based on local wisdom to students through formal education in schools and non-formal education in the community (Iswatiningsih, 2019).

Based on the Law of the Republic of Indonesia Number 20 of 2003 concerning the National Education 
System, it is explained that education is a conscious and planned effort to create an atmosphere of learning and the learning process so that students actively develop their potential to have religious spiritual strength, selfcontrol, personality, intelligence, noble morals, as well as skills needed by himself, society, nation and state. To realize the formation of skills that students must have, it is also strengthened by the Strengthening Character Education program in the Formal Education Unit. Regulation of the Minister of Education and Culture of the Republic of Indonesia Number 20 of 2018 concerning Strengthening Character Education in the Formal Education Unit explains that Strengthening Character Education is carried out by applying the values of Pancasila in character education, especially including religious values, honesty, tolerance, discipline, hard work, creative, independent, democratic, curiosity, national spirit, love for the country, respect for achievement, communicative, love peace, love to read, care for the environment, care about socially, and are responsible. These values are the manifestation of 5 (five) main values which are interrelated, namely religiosity, nationalism, independence, mutual cooperation, and integrity which are integrated in the curriculum.

The competencies listed in the laws and regulations of the Minister above are in accordance with the skills that students must possess in the 21st century, including critical thinking skills and cultural awareness. According to WEF (2015), 21st century skills consist of 16 skills divided into 3 groups, namely basic literacy, competence, and character values. Critical thinking is related to the competence of how students face complex challenges. Critical thinking is defined as the ability to identify, analyze and evaluate situations, ideas and information, responses and solutions. Concern for culture is a character value related to how students deal with a changing environment. Cultural care is defined as the ability to interact with others in ways that are socially, culturally and ethically appropriate. These skills are shown in Figure 1.

Critical thinking skills and awareness of local culture need to be developed through learning, including science learning in junior high schools, considering that these are 21st century competencies that students must possess. To study the process of learning science in schools, in addition to using psychological theory which is rooted in Piaget's individual constructivism (personal constructivism) and a sociological perspective that rests on social constructivism by Vygotsky (social constructivism), researchers and science education experts are currently trying to use studies anthropological theory (anthropological perspective). The latter tries to see the process of learning science in schools in the cultural setting of the surrounding community (Suastra, 2019).

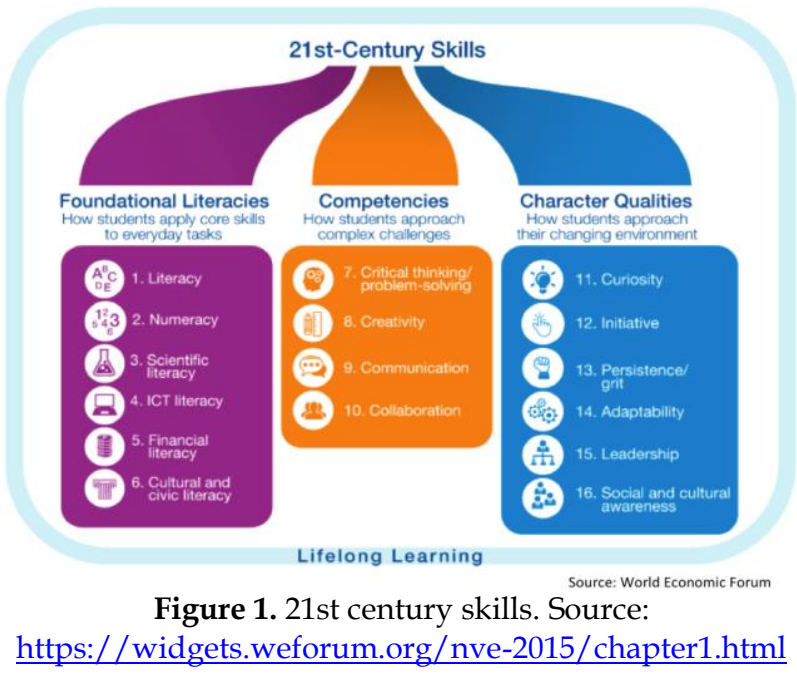

The process of teaching and learning science in the classroom can be likened to the process of transferring and acquiring culture from teachers and by students. For limitation, the word culture (culture) is meant here is a system or structure of symbols and meanings that apply to the social interactions of a society (Geertz, 1992). Caring for local culture can be in the form of liking local culture, introducing local culture to others, and preserving local culture. Meanwhile, critical thinking skills that can be developed in schools according to Ennis (1996) are providing simple explanations, building basic skills, concluding, making further explanations, strategies and tactics.

So that students can develop critical thinking skills and concern for local culture, a learning model is needed that can facilitate students to achieve these goals, including the 5E learning cycle model. According to Bass, et al., (2009), the learning cycle was first developed by Robert Karplus in 1960 in the Science Curriculum Improvement Study (SCIS) program. The learning cycle consists of three phases, namely: discovery, concept invention, and concept application. In 1989, the learning cycle model was developed into the 5E model by the Biological Sciences Curriculum Study. The phase of the 5E learning cycle model adapted from Bass, et al., (2009) is Engage, Explore, Explain, Elaborate and Evaluate.

According to Bybee, et al. (2006), the 5E learning cycle model is not only used in learning science (for example, physics) but can also be applied or implemented in learning technology and mathematics. The five stages contained in the $5 \mathrm{E}$ learning cycle model are designed to facilitate student conceptual change. The 5E learning cycle model is shown in Figure 2. 




Figure 2. 5E Learning Cycle Model. Source: https://knowledgequest.aasl.org/the-5-es-of-inquiry-basedlearning/

Lawson's (2001) research concluded that the learning cycle model has been shown to be effective in helping students form conceptual concepts and systems and developing more effective reasoning patterns, especially since it allows students to use reasoning (if/then/because it) to test their ideas himself who participates in the knowledge construction process. Bybee, et al. (2006) found that the application of the learning cycle has a positive effect on mastery of subject matter, scientific reasoning, and student attitudes towards science.

Based on research conducted by Wilson, Taylor, Kowalski \& Carlson (2010) it can be proven that students in the experimental class who were taught using the 5-E learning cycle model (inquiry-based learning) had much higher learning achievement compared to students in the control class conventional learning model. The study took student subjects aged between 14-16 years. The intended improvement of student learning outcomes includes aspects of knowledge, reasoning, and argumentation. Usmiatiningsih's (2013) research results show that learning physics on the subject matter of Light with the $5 \mathrm{E}$ model is able to develop critical thinking skills and students' attitudes towards science. Students can formulate problems, observe, analyze, present results, and communicate the results of work through class discussions.

Research on the 5E learning cycle model has been widely carried out, but integrating this model with ethnoscience and local wisdom is still rare, especially the local wisdom of the Sasak tribe on Lombok Island. Ethnoscience is knowledge possessed by certain ethnic groups / groups (Sudarmin, 2015). The local wisdom of Lombok Island which has been identified as containing elements of science (ethnoscience) includes Sasak Sade
Village, Bau Nyale Tradition, Sesek Weaving, Gendang Beleq, and Poteng Reket (Hikmawati, et al., 2020).

Based on interviews and questionnaires given to science teachers in Lombok, information was obtained that these teachers did not know information about "ethnoscience" and had never linked local wisdom and culture in Lombok in teaching science in the classroom. In order for the basic competencies and values of local wisdom to be developed through local culture-based science learning, the teacher's role in the learning process is as follows. (1) Give students the opportunity to express their thoughts, to accommodate the concepts or beliefs that students have that are rooted in original science (culture). (2) Presenting students with examples of discrepant events that are actually commonplace according to Western scientific concepts. (3) Play a role in identifying cultural boundaries to be overlooked and guiding students across cultural boundaries, so as to make sense when cultural conflicts arise. (4) Encouraging students to actively ask questions, provide comments, and solve problems, and (5) Motivate students to be aware of the positive and negative effects of Western science and technology on life in their world (Suastra, 2010).

Student character development, especially character development based on local wisdom, is needed. Learning activities that can develop students' character are exploration, concentration, inquiry from various perspectives (scientific, sociocultural, historical), elaboration, and affirmation (Suastra, 2017). Culture in the form of local wisdom has the potential for Ethnoscience to be a source of knowledge that can be explored to increase students' enthusiasm for learning. The correct learning attitude has an impact on the mastery of science concepts which continues at the stage of developing students' critical thinking skills in explaining natural phenomena. Ethnoscience-based science learning shows that students can be directly involved in finding concepts and disclosing phenomena in the environment around students. If the student culture is in accordance with science lessons, it will reinforce each other, but if it is different, it will be developed together in parallel without alienating (Suastra, et al., 2017).

This study aims to analyze the needs (need assessment) of students in learning science in junior high schools which will be used as a basis in designing ethnoscience-based learning models for the development of critical thinking skills and awareness of students' local culture.

\section{Method}

This research is a needs analysis research which will be used as the basis for designing a science 
learning model to develop critical thinking skills and awareness of local culture. The number of respondents involved in filling out the questionnaire was 30 science teachers in Lombok. The data collected in this study included: 1) Science teacher opinion about ethnoscience-based learning; 2) basic science competencies that can be developed in ethnosciencebased learning, 3) relevant methods for ethnosciencebased learning models; 4) relevant learning resources to support ethnoscience-based learning models; 5) relevant assessments for local culture-based learning; 6) Critical thinking skills that can be developed through ethnoscience-based learning models; 7) Attitudes of concern for local cultures that can be developed through ethnoscience-based learning models; 8) ethnoscience-based learning design to develop students' critical thinking skills and local cultural awareness. The research data were collected through field observations, literature review, interviews, and questionnaires. Data were analyzed descriptively.

\section{Result and Discussion}

Local wisdom in Lombok is Weaving, poteng reket, bau nyale, gendang belek, traditional house of the Sasak tribe, Mamak (chewing betel leaf), making brown sugar from palm water that is cooked into solid brown sugar, Purifying 24 carat gold in Sekarbela, making knives from iron to sharp using metal expansion, peresean, Nyongkolan, when yawning shut up, don't breathe when drinking, spur the horse stronger when the load is greater, the process of making Sasak Gumese (Gerung) weaving using natural dyes from fruits, buffalo race, Peresean, Berugak, Begawe, pounding rice using pestle, awik-awik.

The relevant methods used in ethnosciencebased learning to develop critical thinking skills and local cultural awareness are the field observation method 86.7\%, investigation/experiment with a percentage of $60 \%$, and group discussion with $33.3 \%$. The relevant method can be seen in the diagram in Figure 3.

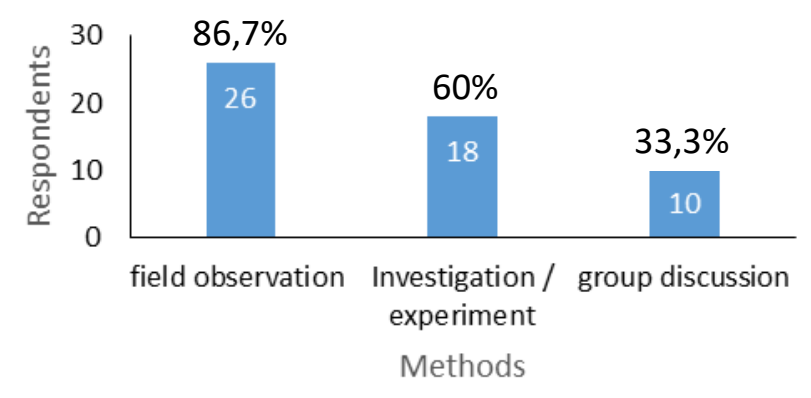

Figure 3. Relevant methods used in ethnoscience-based learning
Relevant learning resources used in ethnoscience-based learning to develop critical thinking skills and the highest concern for local culture are the socio-cultural environment as much as $93,3 \%$, natural environment by $73.3 \%$, audio visual $50 \%$, internet $46 \%$, books $40 \%$. The relevant learning resources can be seen in the form of a diagram in Figure 4.

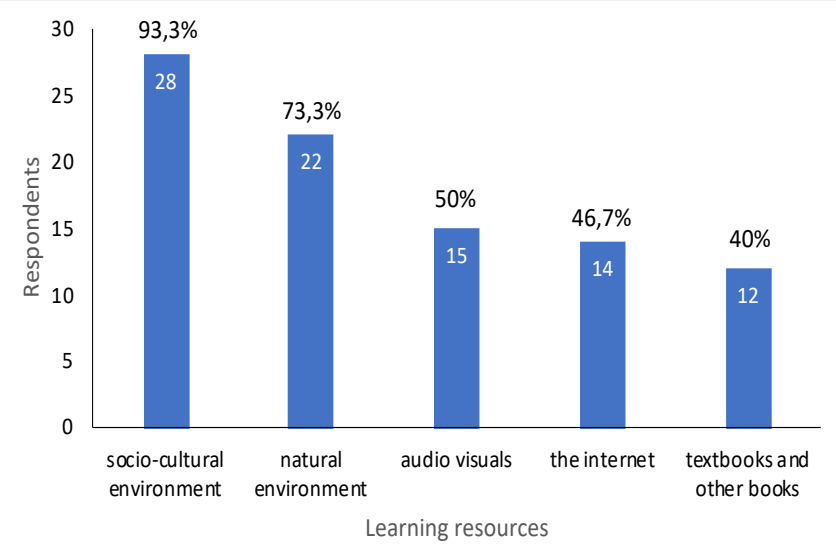

Figure 4. Relevant learning resources used in ethnosciencebased learning

The relevant assessment system used in ethnoscience-based learning to develop critical thinking skills and concern for local culture was the non-test assessment of $96.7 \%$. The relevant scoring system can be seen in diagram form in Figure 5.

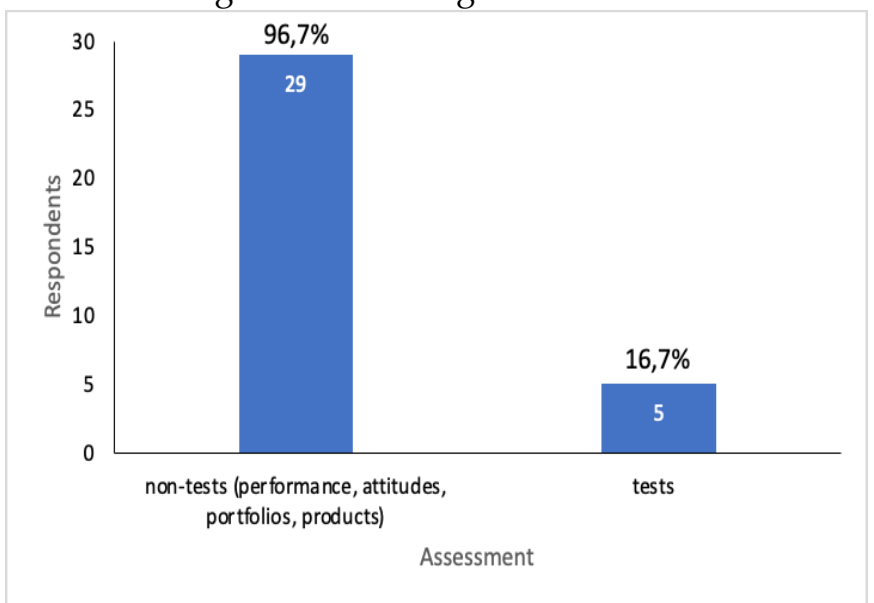

Figure 5. The relevant assessment system used in ethnoscience-based learning

Critical thinking skills that can be developed through ethnoscience-based learning are building basic skills by $73.3 \%$. Other critical thinking skills can be seen in diagram form in Figure 6. 




Figure 6. Critical thinking skills that can be developed through ethnoscience-based learning

The form of concern for local culture that can be developed through ethnoscience-based learning is preserving local culture by $90 \%$, liking local culture by $60 \%$, and introducing local culture to others by $56.7 \%$. Other forms of concern for local culture can be seen in the diagram in Figure 7.



Local cultural concern

Figure 7. A form of local cultural concern that can be developed through ethnoscience-based learning

The respondents' opinions about suitable learning designs in ethnoscience-based learning designs are as follows. The $5 \mathrm{E}$ learning cycle model is suitable in the application of ethnoscience learning to train students' basic abilities. Active students are able to think critically and be able to solve a problem with their own concepts. The application of the 5E learning cycle model can explore the abilities of students. This design is suitable, especially for students whose culture will make them more interested in exploring the elements of science in their culture. The suggestion given by respondents is to add one stage in the $5 \mathrm{E}$ learning cycle model so that there are student activities to showcase local culture according to the material being studied. This is an activity to develop students' caring attitudes towards Sasak culture in Lombok. This stage is called the Exhibit which is placed before the
Evaluate stage, so that the activities in the Exhibit will also strengthen critical thinking skills and develop a caring attitude for local culture. Thus, the learning cycle model that can be used to develop critical thinking skills and local cultural awareness of students in Junior High School is the 6E learning cycle model with stages namely Engage, Explore, Explain, Elaborate, Exhibit, and Evaluate. The mapping of the relationship between the $6 \mathrm{E}$ learning cycle model with critical thinking skills and local cultural awareness in the form of a diagram can be seen in Figure 8.

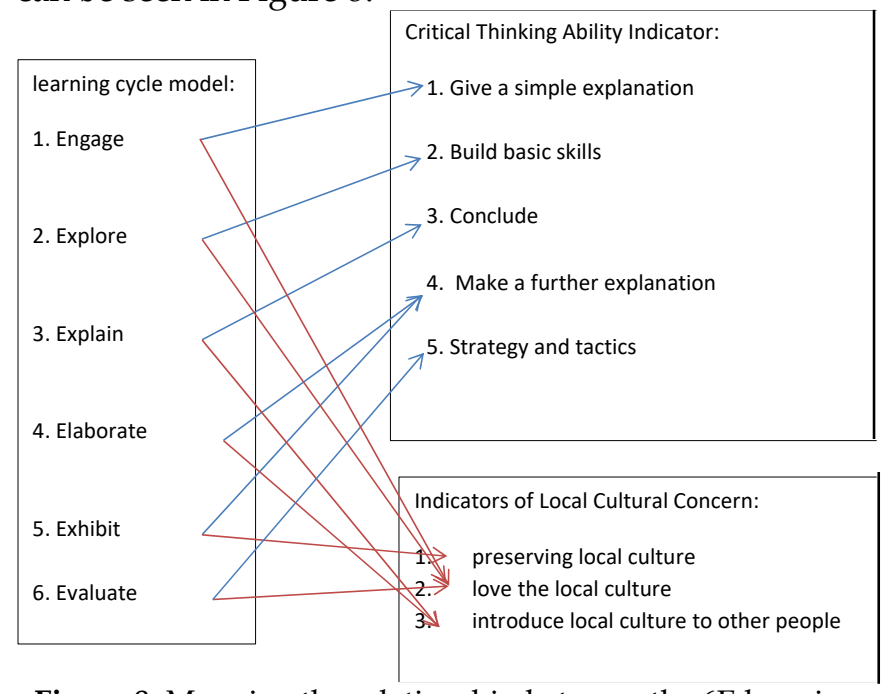

Figure 8. Mapping the relationship between the 6E learning cycle model with critical thinking skills and local cultural concerns

The ethnoscience-based science learning conceptual model, namely the $6 \mathrm{E}$ learning cycle model, has activities in each phase as follows. Each stage in the 6E learning cycle model will be integrated with ethnoscience with the aim of each stage being able to develop critical thinking skills and concern for the local culture of junior high school students. One of the ethnoscience is the Bau Nyale tradition (catching sea worms) which can be integrated into the material on the classification of living things in grade VII in junior high school. The description of the stages of ethnoscience-based $6 \mathrm{E}$ learning is as follows:

1) At the Engage stage, the critical thinking skills developed are to provide simple explanations, while the concern for local culture developed is to like local culture. Teachers can provide motivational perceptions by telling the story of Princess Mandalika to students, either verbally or by providing photos or playing short videos of information about Bau Nyale. Teachers convey basic competencies and learning objectives. Students are asked to express their initial ideas/ideas and beliefs in ethnoscience-based material (Bau Nyale) to be 
taught. The teacher does not justify or blame students' ideas.

2) In the Explore stage, the critical thinking skills developed are building basic skills, while the concern for local culture being developed is liking local culture. The teacher gives students to form small groups (3-5 people) to carry out investigations from various perspectives, such as the history of Princess Mandalika and Bau Nyale, indigenous science (local wisdom of the Sasak tribe), and science The teacher facilitates students to carry out investigations with the help of worksheets based ethnoscience.

3) In the Explain stage, the critical thinking skills developed are concluding, while the cultural concern developed is introducing local culture to others. Students can discuss with each other in their respective groups about the results of the investigation which are assisted by worksheets. Students can be advised to make a report on the results of the investigation by linking the material with the local wisdom of Lombok Island (Bau Nyale Tradition). Students report the results of the investigation on the board.

4) In the Elaborate stage, the critical thinking skills developed are to make further explanations, while the cultural concern developed is to introduce local culture to others. Students present the results of their investigations in front of the class and other students are given the opportunity to argue or comment. The teacher asks open-ended questions to check the basic competencies of students and local wisdom (the story of Princess Mandalika and the Bau Nyale tradition) related to the topics she has studied.

5) At the Exhibit stage, the critical thinking skills developed were to make further explanations, while the concern for local culture developed was to preserve local culture. In this case, the activity can be filled with local cultural exhibitions, it can be in the form of playing a character in the story of Princess Mandalika (Bau Nyale tradition) in front of the class, or by displaying works according to topics/materials and local wisdom. In other words, the teacher can ask students to show off the story of Princess Mandalika so that it turns into Nyale in the form of role playing.

6) At the Evaluate stage, the critical thinking skills developed were strategies and tactics, while the cultural concern developed was liking local culture. The teacher facilitates students to comment, ask questions, and clarify the topics studied which are integrated with local wisdom (the Bau Nyale tradition) and reflect. The teacher provides confirmation of the results of the student's investigation. The teacher provides positive feedback in the form of written and oral praise on student success. The teacher makes an assessment/assessment during the process.

\section{Conclusion}

Based on the results of the research and discussion above, it can be concluded that the following matters. There are 5 local wisdoms of the Sasak tribe in Lombok which can be used in ethnoscience-based learning, namely: Sasak Sade Village, Bau Nyale Tradition, Sesek Weaving, Gendang Beleq, and Poteng Reket. Learning materials related to local wisdom include: Measurement with non-standard units, classification of living things, mixtures and single substances, vibrations and sounds, conventional biotechnology. The relevant methods used in ethnoscience-based learning to develop critical thinking skills and awareness of local culture are field observation, inquiry/experiment, and group discussion methods. Relevant learning resources used in ethnoscience-based learning to develop critical thinking skills and local cultural concerns are the socio-cultural environment, natural environment, audio visual, internet, and books. The relevant assessment system used in ethnoscience-based learning to develop critical thinking skills and local cultural awareness is non-test and test assessments. Critical thinking skills that can be developed through ethnoscience-based learning are providing simple explanations, building basic skills, concluding, making further explanations, strategies and tactics. Forms of local cultural concern that can be developed through ethnoscience-based learning are preserving local culture, liking local culture, and introducing local culture to others. An ethnosciencebased conceptual model of science-based learning that is suitable for developing critical thinking skills and awareness of local culture includes the following steps: Engage, Explore, Explain, Elaborate, Exhibit, and Evaluate.

It is suggested that further studies should be carried out on this research to determine the effectiveness of ethnoscience-based science learning models as an effort to develop critical thinking skills and concern for local culture of students in Lombok.

\section{References}

Bass, J.E., Contant, T.L., \& Carin, A. A. (2009). Teaching Science as Inquiry. USA: Allyn \& Bacon.

Bybee, R.W., Taylor W.A., Gardner A., Scotter P.V., Powell J.C., Westbrook A., Landes N. (2006). The BSCS 5E Instructional Model: Origins and Effectiveness. A Report Prepared for the Office of 
Science Education, National Institutes of Health, Colorado.

Ennis, R.H. (1996). A Critical Thinking. New York: Freeman.

Geertz, C. (1992). Kebudayaan dan Agama. Yogyakarta: Kanisius Press.

Hikmawati, Suastra, I.W., Pujani, N.M. (2020). Local Wisdom Analysis in Lombok Island with the Potential of Ethnoscience for the Development of Learning Models in Junior High School. Paper presented at the International Seminar "10th International Conference on Theoretical and Applied Physics (ICTAP) and the National Physics Symposium (SFN) XXXIII", by the Faculty of Teacher Training and Education, University of Mataram with the theme: "Physical Science Research and Learning Facing Challenges in the Industrial Revolution 4.0 Era" on November 20 and 21, 2020 in Mataram.

Iswatiningsih, D. (2019). Penguatan Pendidikan Karakter Berbasis Nilai-Nilai Kearifan Lokal. Satwika, 3(2), 155-164. doi: https://doi.org/10.22219/SATWIKA.Vol3.No2.1 55-164

Law of the Republic of Indonesia Number 20 of 2003 concerning the National Education System.

Lawson, A.E. (2001). Using the learning cycle to teach biology concepts and reasoning patterns. Journal of Biological Education, (35), (4).

OECD, (2019), PISA 2018 Results (Volume I): What Students Know and Can Do, PISA, OECD Publishing, Paris, https://doi.org/10.1787/5f07c754en.

Regulation of the Minister of Education and Culture of the Republic of Indonesia Number 20 of 2018 concerning Strengthening Character Education in the Formal Education Unit.

Suastra, I., Jatmiko, B., Ristiati, N., \& Yasmini, L. (2017). Developing Characters Based on Local Wisdom of Bali in Teaching Physics in Senior High School. Jurnal Pendidikan IPA Indonesia, 6(2), 306312. doi:https://doi.org/10.15294/jpii.v6i2.10681

Suastra, I. (2010). Model Pembelajaran Sains Berbasis Budaya Lokal Untuk mengembangkan Potensi Dasar Sains dan Nilai Kearifan Lokal di SMP. Jurnal Pendidikan dan Pengajaran, 43(1). doi:http://dx.doi.org/10.23887/jppundiksha.v4 3i1.1697.

Suastra, I. W. (2017). Balinese local wisdom and their implications in science education at school. International Research Journal of Management, IT and Social Sciences, 4(2), 48-57. Retrieved from https://sloap.org/journals/index.php/irjmis/ar ticle/view/446
Suastra I.W. (2019). Integrasi Kearifan Lokal dalam Pembelajaran Fisika dalam Rangka Menyiapkan Sumber Daya Manusia Berkarakter Kuat Menyongsong Era Revolusi Industri 4.0. Seminar Nasional Pendidikan, Program Studi Pendidikan Fisika FKIP ULM Banjarmasin, 23 Maret 2019. 20-31.

Sudarmin. (2015). Pendidikan karakter, Etnosains dan Kearifan Lokal: Konsep dan Penerapannya dalam Penelitian dan Pembelajaran Sains. Semarang: Fakultas Matematika dan Ilmu Pengetahuan Alam, Universitas Negeri Semarang

Usmiatiningsih, E. (2013). Pengembangan Multimedia Interaktif Berbasis Flash dan Implementasinya melalui Model 5E untuk Meningkatkan Keterampilan Berpikir Kritis dan Sikap terhadap Sains. Tesis. Tidak diterbitkan. Mataram: Prodi Magister Pendidikan IPA PPs Universitas Mataram.

Wilson, C. D., Taylor, J. A., Kowalski, S. M., \& Carlson, J. 2010. The relative effects and equity of inquirybased and commonplace science teaching on students' knowledge, reasoning, and argumentation. Journal of Research in Science Teaching, 47(3), 276-301. doi: https://doi.org/10.1002/tea.20329 